\title{
Sequencing of the Canine
} Cytochrome P450 CYP2C41 Gene
and Genotyping of Its Polymorphic
Occurrence in 36 Dog Breeds

\author{
Emre Karakus ${ }^{\ddagger \neq}$, Clarissa Prinzinger ${ }^{\ddagger}$, Silke Leiting and Joachim Geyer* \\ Faculty of Veterinary Medicine, Institute of Pharmacology and Toxicology, Justus Liebig University Giessen, Giessen, Germany
}

\section{OPEN ACCESS}

Edited by:

Deirdre P. Campion,

University College Dublin, Ireland

Reviewed by:

Dora Koller

Yale University, United States James C. Sacco,

Drake University, United States

Johanna Fink-Gremmels,

Utrecht University, Netherlands

*Correspondence:

Joachim Geyer

joachim.m.geyer

@vetmed.uni-giessen.de

TORCID:

Emre Karakus orcid.org/0000-0002-0822-0054

¥These authors have contributed equally to this work and share first authorship

Specialty section: This article was submitted to Veterinary Pharmacology and

Toxicology,

a section of the journal

Frontiers in Veterinary Science

Received: 02 February 2021 Accepted: 25 March 2021

Published: 22 April 2021

Citation:

Karakus E, Prinzinger C, Leiting $S$ and Geyer J (2021) Sequencing of the Canine Cytochrome P450 CYP2C41

Gene and Genotyping of Its Polymorphic Occurrence in 36 Dog Breeds. Front. Vet. Sci. 8:663175. doi: 10.3389/fvets.2021.663175
Cytochrome P450 (CYP) drug metabolizing enzymes play an important role in efficient drug metabolism and elimination. Many CYPs are polymorphic and, thereby, drug metabolism can vary between individuals. In the case of canine CYP2C41, gene polymorphism was identified. However, as the first available canine genome sequences all were CYP2C41 negative, this polymorphism could not be clarified at the genomic level. The present study provides an exact characterization of the CYP2C41 gene deletion polymorphism at the genomic level and presents a PCR-based genotyping method that was used for CYP2C41 genotyping of 1,089 individual subjects from 36 different dog breeds. None of the Bearded Collie, Bernese Mountain, Boxer, Briard, French Bulldog or Irish Wolfhound subjects had the CYP2C41 gene in their genomes. In contrast, in the Chinese Char-Pei, Siberian Husky, Schapendoes and Kangal breeds, the CYP2C41 allele frequency was very high, with values of $67,57,43$, and $34 \%$, respectively. Interestingly, the site of gene deletion was identical for all CYP2C41 negative dogs, and all CYP2C41 positive dogs showed highly homologous sequence domains upstream and downstream from the CYP2C41 gene. CYP2C41 genotyping can now be routinely used in future pharmacokinetic studies in canines, in order to identify genetically-based poor or extensive drug metabolizers. This, together with more extensive in vitro drug screening for CYP2C41 substrates will help to determine the clinical relevance of CYP2C41, and to optimize drug treatment. Although the relative abundance of the CYP2C41 protein in the canine liver seems to not be very high, this CYP could substantially contribute to hepatic drug metabolism in dogs expressing CYP2C41 from both alleles and, when CYP2C41 shows higher catalytic activity to a given drug than other hepatic metabolic enzymes.

Keywords: CYP2C41, dog, drug metabolism, pharmacogenetic, genotyping, gene deletion

\section{INTRODUCTION}

Cytochrome P450 (CYP) metabolizing enzymes play an important role in the efficient metabolism and elimination of many drugs $(1,2)$. It is well-recognized that the activity of CYP-mediated drug metabolism varies considerably between species, breeds and individuals, which is often based on genetic variability (3). As a consequence, clinical outcomes after standard dosing can be less efficient due to high CYP catalytic activity, high drug clearance, and, as a result, suboptimal plasma levels (4). 
Individuals with this phenotype often are referred to as extensive metabolizers. Conversely, CYP deficiency or reduced CYP catalytic activity can result in lower drug clearance, higher drug plasma levels, and, as a result, increases in adverse drug reactions and drug toxicities (5). As an example, the premature stop codon mutation c.1117C $>\mathrm{T}(\mathrm{R} 373 \mathrm{X})$ in canine CYP1A2 results in a complete loss of the hepatic CYP1A2 protein, and a reduction in the associated catalytic activity in homozygous dogs $(6,7)$. This single nucleotide polymorphism (SNP) was discovered during preclinical testing of novel drug candidates (AC-3933 and YM-64227) and was associated with significantly increased drug serum levels (8-10). Genetic variation can also affect the translation efficiency of CYP-coding mRNAs, with the consequence of lower drug metabolism, which is the case for the CYP2B11 haplotypes $\mathrm{H} 2$ and $\mathrm{H} 3(11,12)$. Larger chromosomal regions can also be polymorphic, as is the case for the sparsely characterized CYP2C41. Blaisdell et al. found in 1998 that CYP2C41 cDNA can only be cloned from one out of nine Beagle dogs, whereas CYP2C21 cDNA was present in all nine subjects (13). However, in contrast to the other canine CYPs, the CYP2C41 gene was not present in the first available dog genomes and, therefore, this polymorphism could not be analyzed at the genomic level. Therefore, the goal of the present study was to clone the full sequence of the canine CYP2C41 gene, in order to provide the basis for the development of appropriate genotyping methods. In the present study a PCR-based method for CYP2C41 genotyping is presented as well as data for the breed distribution of this gene deletion polymorphism from 1,089 individual subjects from 36 different dog breeds.

\section{MATERIALS AND METHODS DNA Samples}

Blood samples from client-owned dogs were originally nt230(del4) MDR1 genotyped for clinical diagnostic reasons as part of the pharmacogenetic diagnostic service at the host institute as previously reported (14). Briefly, genomic DNA was isolated from $200 \mu \mathrm{l}$ of EDTA-anticoagulated blood using a DNA isolation kit following manufacturer's instructions (NucleoSpin Blood QuickPure, Macherey, Düren, Germany). Some of these DNA samples then were used for retrospective CYP2C41 genotyping. The dog owners gave consent that the DNA samples can be used for subsequent scientific studies instead of being discarded. No samples were taken specifically for the retrospective analysis presented in the current manuscript and, therefore, this re-analysis did not require ethical approval. In total, 1,089 samples from 36 dog breeds were re-analyzed.

\section{Full-Length PCR-Amplification and Sequencing of the Canine CYP2C41 Gene}

DNA from a CYP2C41-positive Shetland Sheepdog was used to amplify the full-length CYP2C41 gene. Based on sequence alignments between the CYP2C21 (GenBank accession number NM_001197044) and CYP2C41 (GenBank accession number NM_001003334) cDNAs, the exon structure of the CYP2C41 gene was predicted. Respective exon-spanning forward and reverse primers were designed (see Table 1) and used for the amplification of exons 1-9 in both genes. The amplification of all exons was performed in a peqSTAR thermocycler (PeqLab, Erlangen, Germany) with a total volume of $50 \mu$ l. The reactions contained $10 \mu \mathrm{l}$ X Phusion HF Buffer, $1 \mu \mathrm{l} 10 \mathrm{mM}$ dNTPs, $0.5 \mu \mathrm{M}$ of the respective forward and reverse primer, $0.5 \mu$ l Phusion High-Fidelity DNA Polymerase (ThermoFisher Scientific, Dreieich, Germany), and $5 \mu \mathrm{l}$ of DNA. The PCR cycling parameters were as follows: initial denaturation at $98^{\circ} \mathrm{C}$ for $30 \mathrm{~s}, 30$ cycles of $98^{\circ} \mathrm{C}$ for $10 \mathrm{~s}, 52-57^{\circ} \mathrm{C}$ (see Table 1) for $20 \mathrm{~s}$, $72^{\circ} \mathrm{C}$ for $20 \mathrm{~s}$, and final elongation at $72^{\circ} \mathrm{C}$ for $7 \mathrm{~min}$. All PCR products were separated by electrophoresis in $2.5 \%$ agarose gels and stained with ethidium bromide (Sigma Aldrich, Taufkirchen, Germany). The relevant amplicons were excised under UV light, extracted with the GeneJET gel extraction kit (ThermoFisher Scientific), and subjected to DNA sequencing. DNA sequencing was done by Microsynth SeqLab (Göttingen, Germany) using Sanger sequencing. The recommended concentrations for the PCR products were $1.5 \mathrm{ng} / \mu \mathrm{l}$ per $100 \mathrm{bp}$ in $\mathrm{ddH}_{2} \mathrm{O}$. Sequencing primers $(20 \mu \mathrm{M})$ and DNA template solutions were sent separately in $1.5 \mathrm{ml}$ reaction cups. In a similar manner, primers were used to amplify the intron sequences. Sequence alignments were performed with the MegAlign tool of the DNASTAR Lasergene software. All PCR fragments were assembled and the full-length genomic CYP2C41 sequence was deposited into the GenBank database with accession number HF677515.

\section{Amplification and Sequencing of the Sites of Recombination Flanking the CYP2C41 Gene}

To amplify and sequence the sites of recombination (SOR), dog DNA samples were prescreened by PCR for the presence of the CYP2C41 gene (primers EX7-F/R, CYP2C41 exon 7) and the CYP2C21 gene, which was used as a control (primers EX3-F/R, CYP2C21 exon 3) (see Table 1). Then, the sites of recombination of selected CYP2C41-positive dogs were amplified with the primers SOR-F3/R4 (break point SOR1) and SOR-F4/R3 (break point SOR2). In CYP2C41 negative dogs, the SOR break point was amplified with the primers SOR-F3/R3. All PCR reactions were performed using a peqSTAR thermocycler instrument with a total volume of $10 \mu \mathrm{l}$, containing $1 \mu \mathrm{l}$ of genomic DNA, $1 \mu \mathrm{M}$ of each primer, $1 \mathrm{mM}$ dNTPs mix, $1 \mu \mathrm{l}$ of $10 \times$ PCR buffer, and 0.5 units DreamTaq DNA Polymerase (ThermoFisher Scientific). The PCR conditions were as follows: initial denaturation at $95^{\circ} \mathrm{C}$ for $3 \mathrm{~min}, 30$ cycles of $95^{\circ} \mathrm{C}$ for $30 \mathrm{~s}, 59^{\circ} \mathrm{C} / 69^{\circ} \mathrm{C}$ (see Table 1) for $30 \mathrm{~s}, 72^{\circ} \mathrm{C}$ for $60 \mathrm{~s}$, and final elongation at $72^{\circ} \mathrm{C}$ for $5 \mathrm{~min}$. All PCR products were analyzed by electrophoresis in $2 \%$ agarose gels and gel extraction and sequencing procedures were performed as mentioned above.

\section{Screening for the CYP2C41 Gene by Real-Time PCR and Melting Curve Analysis}

Presence of the CYP2C41 gene was screened by multiplex real-time PCR on a StepOnePlus Real-Time PCR instrument (Applied Biosystem, Darmstadt, Germany), using the fluorescent dye SYBR Green PCR-Master-Mix (PowerUp SYBR Master Mix A25742, ThermoFisher Scientific). PCR mixtures contained 
TABLE 1 | Primers used for PCR.

\begin{tabular}{|c|c|c|c|c|c|c|c|}
\hline \multicolumn{2}{|c|}{ Primer name CYP2C21 (sequence $5^{\prime} \rightarrow 3^{\prime}$ ) } & \multirow{2}{*}{$\begin{array}{c}\begin{array}{c}\text { Annealing } \\
\text { temp. }\left({ }^{\circ} \mathbf{C}\right)\end{array} \\
53\end{array}$} & \multirow{2}{*}{$\begin{array}{c}\begin{array}{c}\text { Product } \\
\text { size (bp) }\end{array} \\
163\end{array}$} & \multicolumn{2}{|c|}{ Primer name CYP2C41 (sequence $5^{\prime} \rightarrow 3^{\prime}$ ) } & \multirow{2}{*}{$\begin{array}{c}\begin{array}{c}\text { Annealing } \\
\text { temp. }\left({ }^{\circ} \mathbf{C}\right)\end{array} \\
52\end{array}$} & \multirow{2}{*}{$\begin{array}{c}\begin{array}{c}\text { Product } \\
\text { size (bp) }\end{array} \\
148\end{array}$} \\
\hline EX1-F & TGG ATC TCT TCA TAG TTC TGG & & & EX1-F & CAT GGA TCC AGT TGT GGT TC & & \\
\hline EX2-F & TTA TGG CCC TGT GTT CAC TG & 53 & 128 & EX2-F & CTA TGG CCC TGT ATT CAC TC & 54 & 147 \\
\hline EX2-R & ACA ATG GGA AAT GGC CTC TG & & & EX2-R & ССТ СCA CTA АCT TाT TCG GC & & \\
\hline EX4-F & TCC CTG TGA TCC TAC TाT C & 53 & 150 & EX4-F & TAC CAT GTG ATC CCA CTT TTG & 52 & 153 \\
\hline EX4-R & CAG GAG GTG CTT GAA ATT AG & & & EX4-R & TCC ATG GGG AGC TCA AAA TC & & \\
\hline EX5-F & СTC TAC AAT GCT TTC ССТ C & 53 & 157 & EX5-F & TAC AAT AGT TTC СCT GCT CTC & 57 & 149 \\
\hline EX5-R & AGT AGT CAA TAA AGT CCC GAG & & & EX5-R & TCA ATG AAA TCC CGA GGA TTG & & \\
\hline EX6-F & CAG TCT GAA TIT ACC ATG GAC & 53 & 103 & EX6-F & AAA GCA CAA CCA GCC ATT GG & 52 & 140 \\
\hline EX8-R & CTG AGA AGG CCA TGA AGT AG & & & EX8-R & GAG AAA GCC ATG AAG TAG TC & & \\
\hline EX9-F & AGA GAG TाT GTG TTG GAG AAG & 53 & 155 & EX9-F & ACG AAT TTG TGT GGG AGA AG & 54 & 246 \\
\hline EX9-R & ATA GGA AGG TGG TGT AGC AC & & & EX9-R & GAA TGA TAC CCC AGA GGA AGA G & & \\
\hline Primer name & Primer sequence & $\left(5^{\prime} \rightarrow 3^{\prime}\right)$ & & & Annealing temp. $\left({ }^{\circ} \mathrm{C}\right)$ & Pro & uct size (bp) \\
\hline SOR-F3 & GAA TTC GGT CA & TAG ACA AG & TGA AAA A & & 59 & & 506 \\
\hline SOR-R3 & CTG GTG AGT TC & A GAG TाT GC & & & & & \\
\hline SOR-F3 & GAA TTC GGT CA & TAG ACA AG & TGA AAA A & & 59 & & 366 \\
\hline SOR-R4 & GAG GAG ACA C & T TGA AAC T & GTA ACT A & ता C & & & \\
\hline SOR-F4 & CTT TGG GCC AC & T GTG ACC & & & 69 & & 1018 \\
\hline
\end{tabular}

$0.1 \mu \mathrm{M}$ EX7-F/R primers for CYP2C41, and $0.3 \mu \mathrm{M}$ EX3-F/R primers for CYP2C21, $5 \mu \mathrm{l}$ SYBR green master mix, and $1 \mu \mathrm{l}$ of DNA in a final volume of $10 \mu \mathrm{l}$. General PCR conditions were initial denaturation at $95^{\circ} \mathrm{C}$ for $10 \mathrm{~min}$ and 40 cycles of $95^{\circ} \mathrm{C}$ for $15 \mathrm{~s}, 56^{\circ} \mathrm{C}$ for $30 \mathrm{~s}$, and $72^{\circ} \mathrm{C}$ for $30 \mathrm{~s}$. The level of fluorescence of the dsDNA-bound SYBR green dye was recorded for each sample after product extension, which allowed close monitoring of the amplification reaction. Since each amplified fragment is characterized by its apparent melting temperature (Tm), which is a function of product length and base composition, a subsequent melting curve analysis could be performed under the following conditions: $95^{\circ} \mathrm{C}$ for $15 \mathrm{~s}, 60^{\circ} \mathrm{C}$ for $1 \mathrm{~min}$, and then increasing to $95^{\circ} \mathrm{C}$ at five acquisitions per ${ }^{\circ} \mathrm{C}$. Each amplified fragment was identified by converting its specific melting curve, measured as fluorescence emission decrease, to a melting peak by the software.

\section{CYP1A2 and MDR1 Genotyping With TaqMan Allelic Discrimination Analysis}

Fluorogenic $5^{\prime}$ nuclease TaqMan allelic discrimination (AD) analysis was used for CYP1A2 1117C > T and nt230(del4) MDR1 genotyping, as previously reported $(15,16)$ using gene-specific oligonucleotide primers and fluorescence-labeled allele-specific oligonucleotide probes (Applied Biosystems). Real-time PCR amplification was carried out in a total reaction volume of $25 \mu \mathrm{l}$, consisting of $12.5 \mu \mathrm{l}$ TaqMan genotyping master mix (Applied Biosystems), including AmpliTaq Gold DNA polymerase, dNTP mix, reaction buffer and ROX reference dye, $2.5 \mu$ l TaqMan $\mathrm{AD}$ assay, and $100 \mathrm{ng}$ of genomic DNA. The samples were amplified in 96-well optical plates on a StepOnePlus realtime PCR instrument (Applied Biosystem). The amplification reaction was started with activation of the AmpliTaq Gold DNA polymerase at $95^{\circ} \mathrm{C}$ for $10 \mathrm{~min}$, before 40 cycles of $92^{\circ} \mathrm{C} \times 15 \mathrm{~s}$ and $60^{\circ} \mathrm{C} \times 30 \mathrm{~s}$ were applied.

\section{RESULTS}

\section{Polymorphic Occurrence of the Entire CYP2C41 Gene in Dogs}

When this project was started in 2012, canine genetic information was still limited, and the only available genome sequence was from a CYP2C41 negative dog (Boxer named Tasha, see Table 2). Therefore, the presence and chromosomal localization of the CYP2C41 gene was not clear at that time. Direct comparison between human chromosome 10 and dog chromosome 28 segments revealed similar CYP2C gene regions, flanked by the genes HELLS and PDLIM1 in both species 
TABLE 2 | Available genomic CYP2C41 sequences of the dog.

\begin{tabular}{|c|c|c|c|c|}
\hline Dog breed & Genomic DNA/cDNA & $\begin{array}{l}\text { GenBank (assembly) accession } \\
\text { number }\end{array}$ & CYP2C41 gene status & $\begin{array}{l}\text { Available since/ } \\
\text { current version } \\
\text { (Reference) }\end{array}$ \\
\hline Not specified & cDNA & $\begin{array}{l}\text { NM_001003334.1 } \\
\text { AF016248.1 }\end{array}$ & Full-length CYP2C41 cDNA & $1998(13)$ \\
\hline Mixed breed & cDNA & HF679527.1 & Full-length CYP2C41 cDNA & 2013 (Prinzinger and Geyer) \\
\hline $\begin{array}{l}\text { Shetland } \\
\text { Sheepdog }\end{array}$ & Genomic DNA & HF677515.1 & Full-length CYP2C41 gene & 2013 (Prinzinger and Geyer) \\
\hline Basenji & Genome assembly Basenji_breed-1.1 & GCA_004886185.1 & CYP2C41 negative & 2019 \\
\hline Great Dane & Genome assembly UMICH_Zoey_3.1 & $\begin{array}{l}\text { GCA_005444595.1 } \\
\text { NC_049288.1 }\end{array}$ & CYP2C41 negative & 2019 \\
\hline Labrador Retriever & Genomic DNA chromosome 28b & $\begin{array}{l}\text { GCA_008641245.1 } \\
\text { CP050626 }\end{array}$ & CYP2C41 positive & 2020 \\
\hline German Shepherd & Genomic DNA chromosome 28 & CM021989 & CYP2C41 negative & 2020 \\
\hline Boxer & $\begin{array}{l}\text { Genome assembly } \\
\text { Dog10K_Boxer_Tasha }\end{array}$ & NC_006610.4 & CYP2C41 negative & 2021 \\
\hline Basenji & $\begin{array}{l}\text { Genome assembly } \\
\text { UNSW_CanFamBas_1.0 }\end{array}$ & NC_049769.1 & CYP2C41 positive & 2021 \\
\hline
\end{tabular}

(Figure 1A). As all four human CYP2C genes (CYP2C8, C9, C18, and C19) typically cluster, localization of the canine CYP2C41 gene was predicted to be in proximity with the CYP2C21 gene. Based on data from the present study, the CYP2C41 gene could be clearly localized between the HELLS and CYP2C21 genes in the same chromosomal orientation as the human CYP2C18, C19, and $\mathrm{C} 9$ genes.

Originally it was not known if the entire CYP2C41 gene was deficient in canine breeds or just parts of it. Therefore, the previously published 1,470 bp CYP2C41 cDNA (13) was used for sequence alignments in sections of the genomic sequence of the canine CYP2C21 gene to predict potential exon regions and exon/exon boundaries of CYP2C41. Then, based on CYP2C41 cDNA, specific oligonucleotide forward and reverse primers were designed for each predicted exon, and used for PCR amplification from different canine genomic DNAs. For comparison, primers specific for each CYP2C21 exon were used. As indicated in Figure 1B for two representative subjects, all nine predicted CYP2C41 exons could be amplified with the predicted amplicon lengths (dog 1), or all CYP2C41 PCR reactions were negative $(\operatorname{dog} 2)$. This indicates polymorphic absence of the entire CYP2C41 gene and not only parts of it. For comparison, all nine CYP2C21 exons from both subjects were amplified, demonstrating presence of the full-length CYP2C21 gene independent of the presence of the CYP2C41 gene.

\section{Full-Length CYP2C41 Gene Sequencing and Assembly}

In the next step, the predicted exon sequences were used for intron-spanning PCR amplification with different pairs of forward and reverse primers from genomic DNA of CYP2C41 positive subjects. All amplicons were subjected to DNA sequencing. Primer sequences were designed in such a way as to obtain overlapping DNA fragments, so that the full-length genomic sequence of the canine CYP2C41 gene could be assembled. This genomic sequence was entered into the GenBank database in 2013 under accession number HF677515 (see Table 2). Comparative analysis of the exonintron organization of the CYP2C41 and CYP2C21 genes revealed identical exon sizes for both genes (see Tables 3, 4, respectively), but overall, the CYP2C21 gene is somewhat larger compared to the CYP2C41 gene. However, at the time this procedure was carried out, the exact chromosomal location of the CYP2C41 gene was still unknown and it was not possible, despite intensive efforts using long-range PCR with the flanking HELLS and PDLIM1 genes, to specify the localization of the newly sequenced CYP2C41 gene within the CYP2C gene cluster. During revision of this manuscript, the gray wolf (Canis lupus) genome assembly of chromosome 28 was made available at GenBank with accession number HG994413. This sequence was used for direct comparison of the CYP2C gene cluster between the dog and the wolf. Interestingly, the gray wolf exhibits two genes, CYP2C21 and CYP2C41, which are highly similar to the respective canine orthologs.

\section{Screening for CYP2C41 Positive Canine Subjects by Multiplex Real-Time PCR}

The CYP2C41 genomic information was used to set up a method to screen for presence of the CYP2C41 gene in a larger cohort of canine subjects. Primer pairs specific for exon 3 of CYP2C21 (EX3-F/R) and exon 7 of CYP2C41 (EX7-F/R) were used for single gene amplification, as well as for multiplex PCR as shown in Figure 2. PCR amplification was performed in a real-time PCR cycler, and the use of SYBR green dye allowed the monitoring of amplification of double-stranded DNA. Subsequent melting curve analysis revealed Tm values of $78.8^{\circ} \mathrm{C}$ and $83.6^{\circ} \mathrm{C}$ for the CYP2C21 and CYP2C41 amplicons, respectively (Figure 2A). So, both amplicons could be separately identified using the multiplex PCR approach. Representative PCR amplicons were then subjected to agarose gel electrophoresis, and this analysis 
A Human chromosome 10

HELLS $>$ CYP2C18 $\quad$ CYP2C19 $>$ CYP2C9 $>$ CYP2C8 $>$ PDLIM1

\section{Dog chromosome 28}

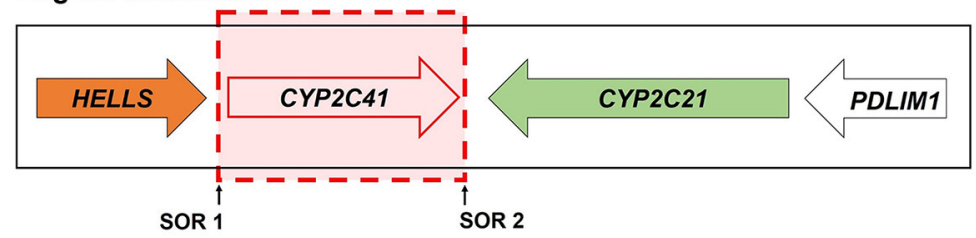

B

\section{CYP2C41}

CYP2C21
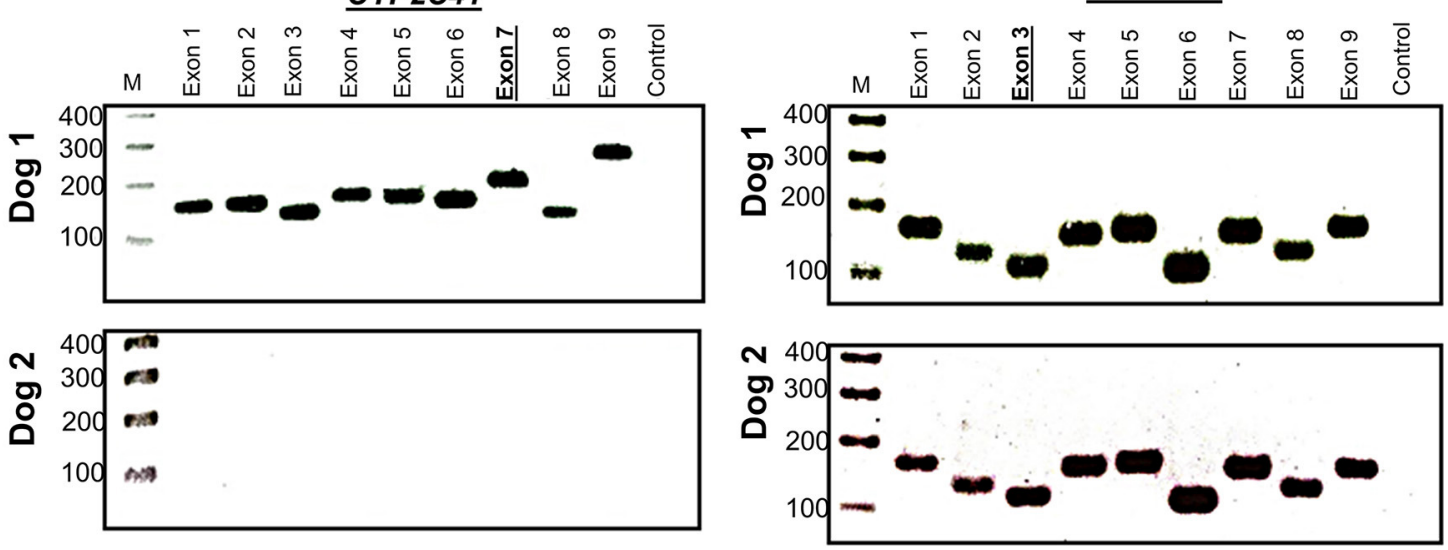

C

CYP2C41 positive dog (GenBank: CM023390.1)

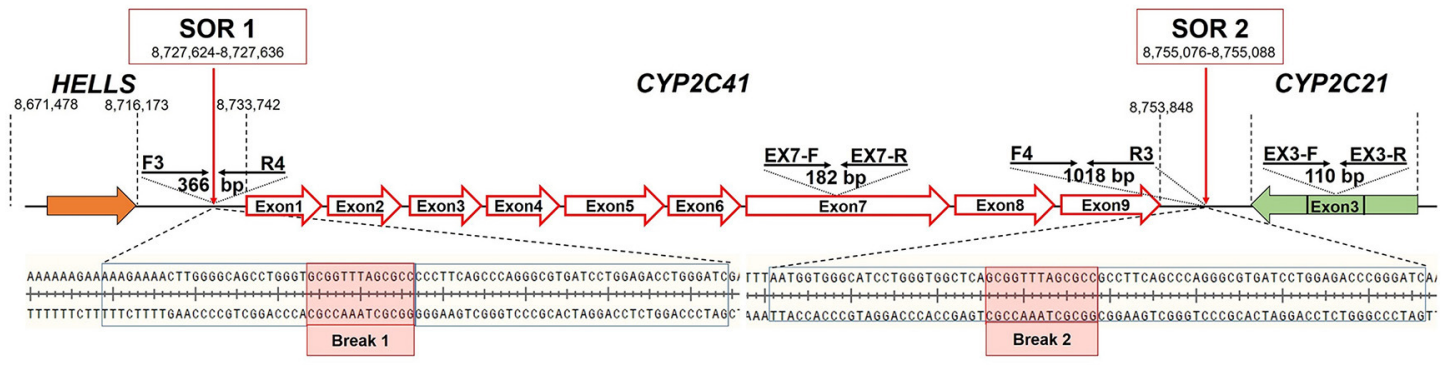

CYP2C41 negative dog (GenBank: CM016596.1)

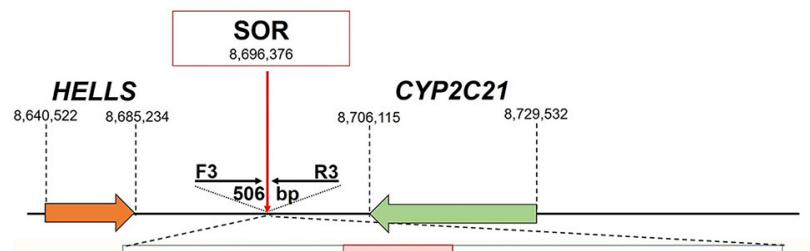

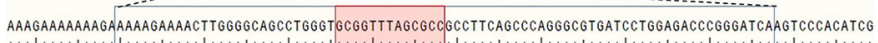

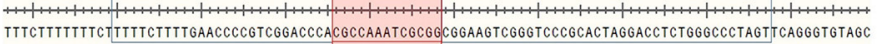
Break

FIGURE 1 | Genomic CYP2C41 gene deletion polymorphism. (A) Chromosomal localization and organization of human and canine CYP2C gene clusters on chromosomes 10 and 28, respectively. Gene arrangements with corresponding proportions derived from the NCBI Genome Data Viewer (www.ncbi.nlm.nih.gov). 
FIGURE 1 | Both gene clusters are bordered by the HELLS and PDLIM1 genes. The canine CYP2C41 gene was schematically introduced based on experimental data from the present study, which demonstrated localization downstream of the HELLS gene. Sites of recombination (SOR 1 and SOR 2) are indicated. (B) Oligonucleotide primers specific for each proposed exon of the CYP2C41 gene were used for PCR amplification from DNAs from different subjects. Data are representatively shown for a CYP2C41 positive subject (dog 1) and a CYP2C41 negative subject (dog 2). As a control, all CYP2C21 gene coding exons were also amplified with gene-specific primers. All amplicons were separated by agarose gel electrophoresis. M, molecular weight DNA marker (100-400 bp). The underlined exons were also examined in subsequent analyses. (C) Schematic presentation of the CYP2C41 genotyping strategy. Subjects were screened for the presence of the CYP2C41 gene with the oligonucleotide primers EX7-F/R, both located on exon 7 of the CYP2C41 gene. The primers EX3-F/R were used as controls to amplify exon 3 from the CYP2C21 gene. Amplification with the primers SOR-F3/R4 or SOR-F4/R3 only produced positive results in the presence of the CYP2C41 gene, whereas amplicons with the primers SOR-F3/R3 indicated the CYP2C41 gene deletion. Of note, DNA sequence patterns were identical at break points 1 and 2 of all CYP2C41 positive subjects (indicated by red boxes). In addition, the exact positions of the respective gene segments are indicated.

TABLE 3 | EXon-intron organization of the canine CYP2C41 gene.

\begin{tabular}{lllll}
\hline Exon & $\begin{array}{l}\text { CDS length } \\
(\mathbf{b p})\end{array}$ & $\mathbf{5}^{\prime}$-Splice donor & $\begin{array}{l}\mathbf{3}^{\prime} \text {-Splice } \\
\text { acceptor }\end{array}$ & $\begin{array}{l}\text { Intron } \\
\text { size (bp) }\end{array}$ \\
\hline & & ATGGAT... & & \\
1 & 165 & AGTAAT/gtaagt & tctcag/CTCTCA & 1,411 \\
2 & 163 & GACACG/gtaggt & tggtag/GAATCA & 169 \\
3 & 150 & CCAATG/gtgagt & cttag/CCTAC & 4,249 \\
4 & 161 & ATCCAG/gtgagg & tttaag/GCCTAC & 2,452 \\
5 & 177 & GAACAG/gtaaaa & tcctag/GAAAAG & 2,859 \\
6 & 142 & TCACAG/gtatgg & tatcag/TGAAAG & 159 \\
7 & 188 & CCCAAG/gtaaga & ttccag/GGCACA & 5,452 \\
8 & 142 & CAGCAG/gtaata & tttcag/GAAAAC & 1,820 \\
9 & 182 & GTGTGA & &
\end{tabular}

Nucleotide sequences of the exon/intron junctions are indicated according to GenBank accession numbers HF677515, NC_049769.1, and GCA_008641245.1. Exon sequences are shown in uppercase letters, intron sequences are in lowercase. Start codon and stop codon are indicated in bold.

confirmed the correct sizes of the amplicons for CYP2C41 exon 7 (primers EX7-F/R, $182 \mathrm{bp}$ ) and CYP2C21 exon 3 (primers EX3-F/R, $110 \mathrm{bp}$ ). However, a limitation of this method is that discrimination between the homo- or heterozygous occurrence of the CYP2C41 gene is not possible (Figure 2B).

\section{Determination of CYP2C41 Recombination Sites}

Genomic sequences only recently became available from two CYP2C41 positive Labrador Retriever and Basenji subjects (see Table 2). This enabled the complete assembly of the canine CYP2C gene cluster as presented in Figure 1C. Of note, the site of $\mathrm{CYP} 2 \mathrm{C} 41$ gene integration into the canine genome (site of recombination, SOR) is characterized by a specific sequence ( $5^{\prime}$-GCGGTTTAGCGCC- $\left.3^{\prime}\right)$ that is duplicated upstream and downstream of the CYP2C41 gene and represents the break point of the CYP2C41 gene integration (see Figure 1C). PCR amplifications across recombination sites for a larger number of CYP2C41 positive (SOR1 and SOR2) and CYP2C41-negative (SOR) subjects revealed that the sequences on either side of this break point were highly conserved and even the gray wolf showed homologous sequences flanking SOR1 and SOR2 (Supplementary Figure 1). Only in very few exceptions, namely few Bulldog, Shar-Pei, and Kangal dogs, additional
TABLE 4 | Exon-intron organization of the canine CYP2C21 gene.

\begin{tabular}{lcllc}
\hline Exon & $\begin{array}{c}\text { CDS length } \\
\text { (bp) }\end{array}$ & $\mathbf{5}^{\prime}$-Splice donor & $\begin{array}{l}\mathbf{3}^{\prime} \text {-Splice } \\
\text { acceptor }\end{array}$ & $\begin{array}{c}\text { Intron } \\
\text { size (bp) }\end{array}$ \\
\hline & & ATGACT... & & \\
1 & 339 & AGCAAG/gtaggt & tcccag/CTAGCA & 1,901 \\
2 & 163 & GATTAG/gtatgt & tgatag/GAATTG & 1,719 \\
3 & 150 & CCAACG/gtgtgt & tttag/CATCTC & 2,137 \\
4 & 161 & ATACAG/gtaagg & tttcag/CTCTAC & 1,804 \\
5 & 177 & GAAAAG/gtaaaa & ttgtag/GAAAAA & 950 \\
6 & 142 & TCACAG/gtatgg & tgccag/CTAAAG & 2,653 \\
7 & 188 & CCCAAG/gtgaga & tatcag/GGCACA & 3,935 \\
8 & 142 & CAGCAG/gcaagc & ttttag/GGAAGA & 6,360 \\
9 & 182 & GTCTGA & & \\
\hline
\end{tabular}

Nucleotide sequences of the exon/intron junctions are indicated. Exon sequences are shown in uppercase letters, intron sequences are in lowercase. Start codon and stop codon are indicated in bold.

sequence insertions were detected upstream from SOR1 (Supplementary Figure 2).

\section{PCR-Based Method for CYP2C41 Genotyping}

This novel genomic information enabled the setting up of an additional PCR method that allowed the exact determination of the CYP2C41 genotype of a subject from a genomic DNA sample. In this approach, amplification with primers F3/R4 flanking SOR1 resulted in the amplification of a $366 \mathrm{bp}$ fragment, demonstrating the presence of the CYP2C41 gene. In contrast, amplification with primers F3/R3 flanking SOR amplified a $506 \mathrm{bp}$ PCR fragment that indicated the absence of the CYP2C41 gene. Combination of the forward primer F3 with both reverse primers $\mathrm{R} 3$ and $\mathrm{R} 4$ allowed the detection of the heterozygous CYP2C41(+/-) genotype by amplification of both (366 bp $+506 \mathrm{bp})$ fragments. In this assay, exclusive occurrence of the $366 \mathrm{bp}$ or the $506 \mathrm{bp}$ fragment indicated the homozygous CYP2C41(+/+) or CYP2C41(-/-) genotypes, respectively (Figure 3 ).

\section{CYP2C41 Genotyping of 1,089 Subjects From 36 Dog Breeds}

Using this genotyping method, a cohort of 1,089 subject from 36 different canine breeds was genotyped for the occurrence of the CYP2C41 gene. As indicated in Table 5, 

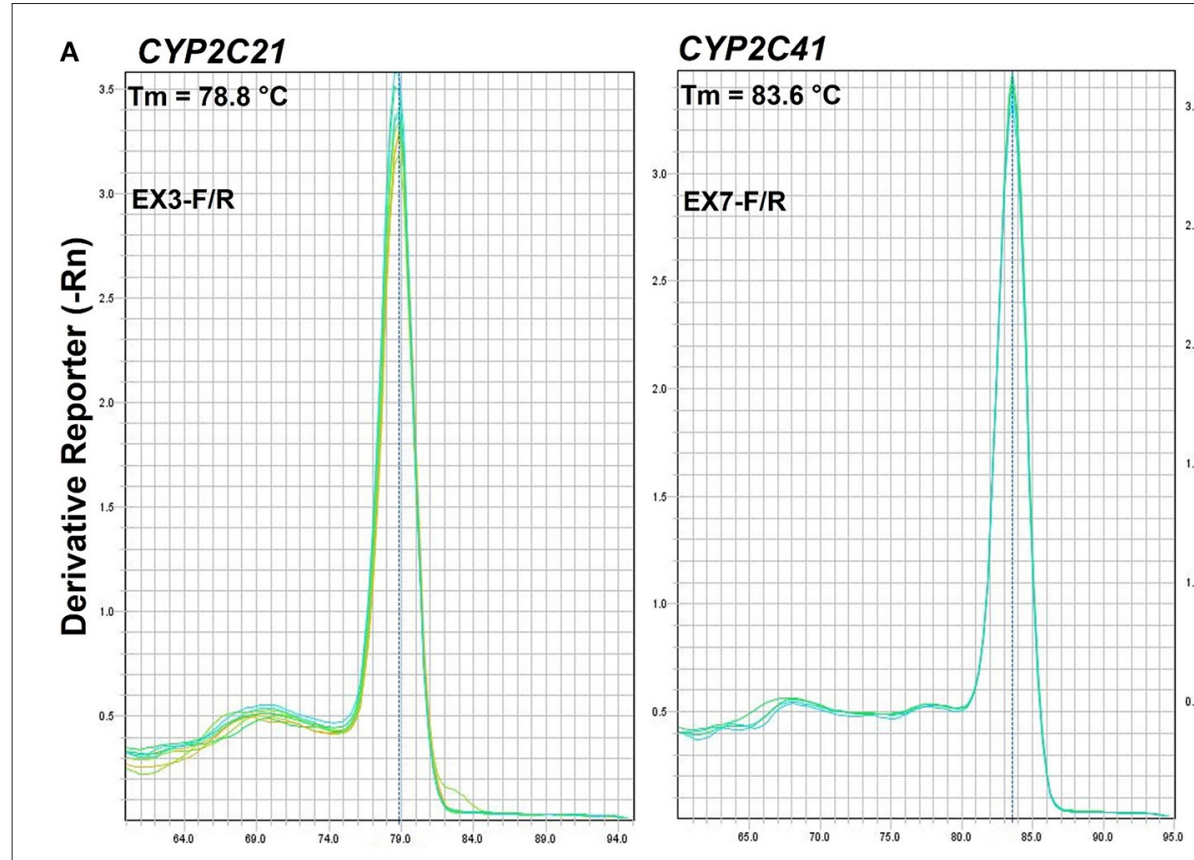

\section{CYP2C21 and CYP2C41}

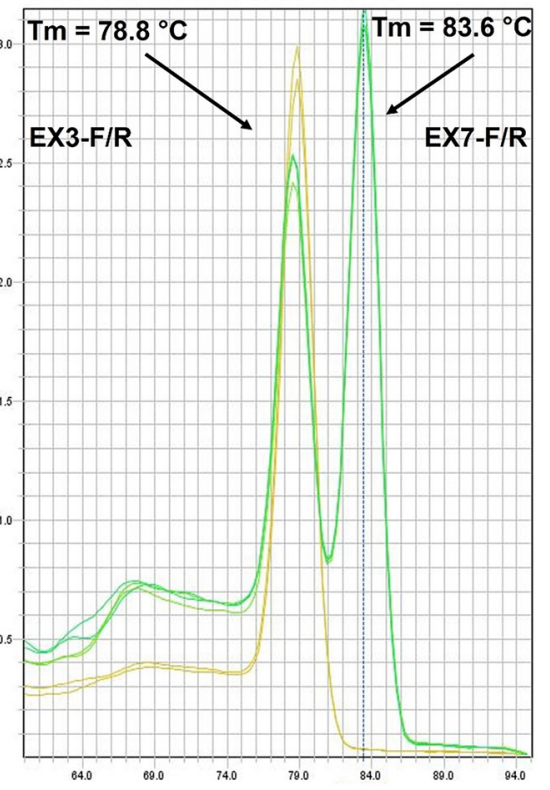

B

\section{EX7-F/R}

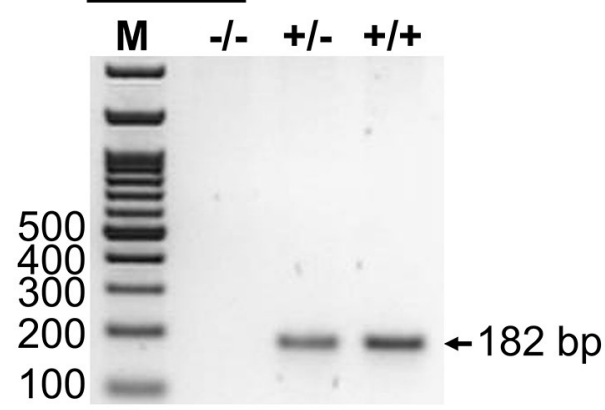

EX3-F/R

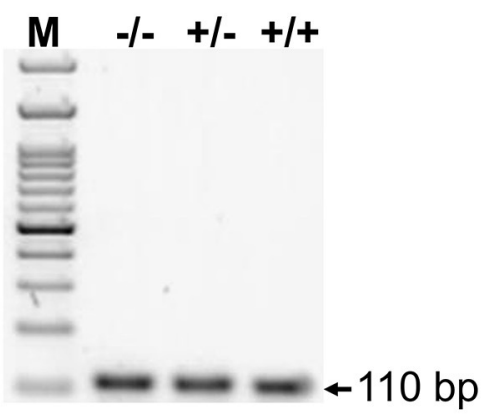

EX7-F/R and EX3-F/R

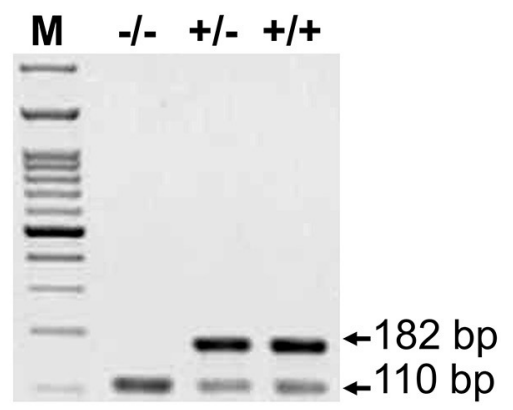

FIGURE 2 | Screening for presence of the CYP2C41 gene. (A) Multiplex PCR and melting curve analysis for simultaneous detection of the CYP2C21 (primers EX3-F/R, Tm $=78.8^{\circ} \mathrm{C}$ ) and CYP2C41 (primers EX7-F/R, Tm $=83.6^{\circ} \mathrm{C}$ ) genes. Multiplex PCR with primers EX3-F/R and EX7-F/R revealed identical melting curves as the single gene PCRs with primers EX3-F/R or EX7-F/R. (B) The PCR products were separated on $2 \%$ agarose gels followed by visualization with ethidium. Representative data for all three CYP2C41 genotypes: (+/+), homozygous positive; (+/-), heterozygous; and (-/-), homozygous negative. Amplification with the primers EX7-F/R revealed PCR fragments of $182 \mathrm{bp}$, indicating the presence of the CYP2C41 gene, and amplification of CYP2C21 exon 3 with the primers EX3-F/R revealed $110 \mathrm{bp}$ fragments. By using multiplex PCR, both fragments were detected. M, molecular weight DNA marker.

the breeds Bearded Collie, Bernese Mountain Dog, Boxer, Briard, French Bulldog, and Irish Wolfhound revealed the most striking results, as among the 29-30 subjects from each tested breed, no subject was CYP2C41 positive. On the contrary, Chinese Char-Pei, Siberian Husky, Schapendoes and Kangal subjects showed relatively high CYP2C41 allelic frequencies of $67,57,43$, and $34 \%$, respectively, while the results from the other dog breeds fell somewhere in between these values. Of note, subjects with CYP2C41 genes on both alleles $[\mathrm{CYP} 2 \mathrm{C} 41(+/+)]$ were quite rare in most of the breeds (Table 5).

\section{Breed-Clustering of the CYP2C41 Polymorphism in Comparison With MDR1 and CYP1A2 Polymorphisms}

This inhomogeneous distribution across breeds was not surprising, as similar results had been detected before for other pharmacogenetic markers, such as the nt230(del4) MDR1 mutation $(14,17-19)$, or the CYP1A2 1117C $>\mathrm{T}$ transition $(7,16)$. To analyze if there was any overlap in the breed distribution pattern between these three pharmacogenetic markers, all 1,089 subjects were additionally genotyped for the CYP1A2 1117C >T marker. The nt230(del4) MDR1 


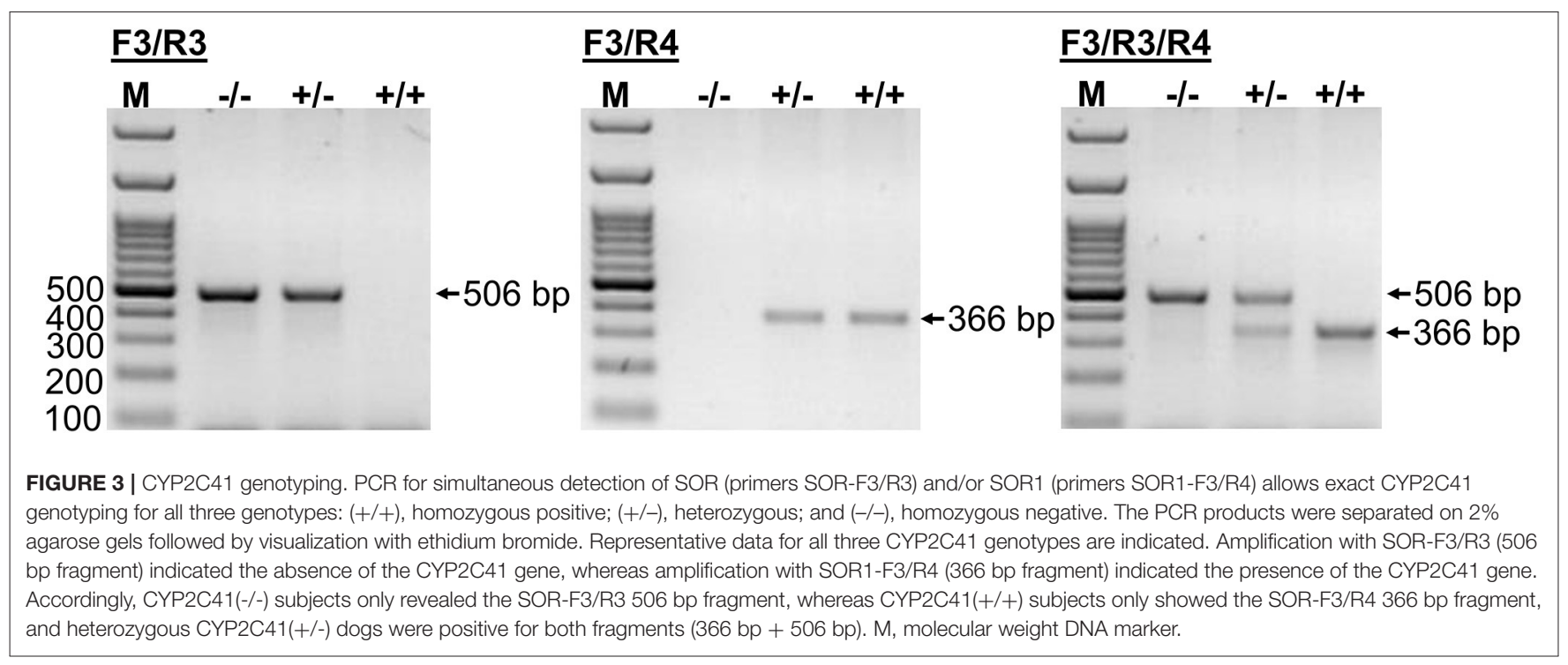

genotypes were already known for each subject based on data from the institute's pharmacogenetic diagnostic service. Genotyping data were then plotted on cladograms that were adapted from Parker et al. (20). The CYP1A2 1117C > T polymorphism most frequently occurred in sighthounds, herding breeds and working dogs, but was also detected in some other clades (Figure 4C), while the nt230(del4) MDR1 mutation occurred exclusively in Whippets, herding breeds and working dogs (Figure 4B). In contrast, the CYP2C41 gene occurred in all breed clades (Figure 4A), with most frequent occurrence at the more ancient Asian Spitz clade, as well as Schapendoes and Kangal breeds. Based on this analysis, the CYP2C41 polymorphism can be regarded as the most widespread among the three markers tested.

\section{DISCUSSION}

\section{The CYP2C Family in Different Species}

Among all CYPs involved in hepatic drug metabolism, the subfamily CYP2C is of particular interest in the context of canine-to-human comparison, as notable species differences exist in the CYP2C subfamily. At present, four CYP2C genes have been identified in humans (21), five in rats (22), 15 in mice (23), two in cats (24), and two in horses (25). Genetic polymorphisms in CYP2C genes have been shown to be of clinical relevance in humans (26). As an example, CYP2C9*2 or *3 allele carriers are poor metabolizers of a number of clinically used medications, and have increased risk for adverse drug reactions, such as can occur after the administration of tolbutamide, NSAIDs, or warfarin (27). Although the clinical significance of canine CYP2C41 gene deletion polymorphism is not entirely clear, it can be stated that a gene deletion polymorphism within the CYP2C gene cluster is unique in canines.

\section{Current Characterization of Canine CYP2C41}

Blaisdell et al. first analyzed the canine CYP2C family more in detail (13). They screened a canine liver cDNA library for closely homologous sequences with a $275 \mathrm{bp}$ probe derived from CYP2C21. They identified a new canine CYP2C cDNA sequence of $1.800 \mathrm{bp}$ with a complete open reading frame, encoding for the 489 aa CYP2C41 protein. Canine CYP2C21 and CYP2C41 have $70 \%$ nucleotide and amino acid sequence identities. Of note, CYP2C41 is more homologous to human CYP2Cs (amino acid sequence similarity $\sim 75 \%$ ) than CYP2C21 (amino acid sequence similarity $\sim 70 \%$ ). By using PCR-based testing, it was shown that from 28 individual subjects (18 Beagles and 10 mixed breeds) all were CYP2C21 positive, but only $4(14 \%)$ were positive for CYP2C41. As these CYP2C41-positive subjects included Beagles, mixed breeds, and male and female subjects, the presence of the CYP21C41 gene was considered to be independent of the breed and gender of the subject (13). Subsequent studies then focused on the catalytic activity of canine CYP2C proteins and addressed the question of if differences in the catalytic activity between human and canine liver microsomes can be attributed to canine genetic variability including CYP2C41. In this context, Graham et al. analyzed the expression of canine liver CYPs and detected CYP2C41 mRNA in only 5 out of 11 subjects (28). In a more recent study, Martinez et al. used TaqMan gene expression assays to quantitatively compare the gene copy numbers for CYP2C41 and UGT1A (29). They were able to discriminate potential heterozygous and homozygous carriers of the CYP2C41 gene. In addition, they analyzed the absolute expression of 11 drugmetabolizing CYPs by means of LC-MS/MS, including CYP2C41, from liver samples of 59 subjects from different canine breeds. They found quantifiable amounts of CYP2C41 only in 12 of the 59 samples. Compared to other CYPs such as CYP2D15 or CYP3A12, CYP2C41 showed relatively low protein abundance in the liver (29). However, 11 of these 12 samples seemed to only contain one copy of the CYP2C41 gene, which could have 
TABLE 5 | CYP2C41 genotyping of 1,089 subjects from 36 dog breeds.

\begin{tabular}{|c|c|c|c|c|c|}
\hline \multirow[b]{2}{*}{ Dog Breed } & \multirow[b]{2}{*}{$N$} & \multicolumn{3}{|c|}{ CYP2C41 genotype } & \multirow[b]{2}{*}{$\begin{array}{l}\text { CYP2C41 allele } \\
\text { frequency (\%) }\end{array}$} \\
\hline & & $-/-$ & $+/-$ & $+/+$ & \\
\hline Bearded Collie & 30 & 30 & 0 & 0 & 0 \\
\hline Bernese Mountain Dog & 30 & 30 & 0 & 0 & 0 \\
\hline Boxer & 30 & 30 & 0 & 0 & 0 \\
\hline Briard & 29 & 29 & 0 & 0 & 0 \\
\hline French Bulldog & 30 & 30 & 0 & 0 & 0 \\
\hline Irish Wolfhound & 30 & 30 & 0 & 0 & 0 \\
\hline Australian Shepherd & 30 & 29 & 1 & 0 & 1.7 \\
\hline Old English Sheepdog & 30 & 29 & 1 & 0 & 1.7 \\
\hline Golden Retriever & 30 & 29 & 1 & 0 & 1.7 \\
\hline Labrador Retriever & 30 & 29 & 1 & 0 & 1.7 \\
\hline Bulldog & 32 & 30 & 2 & 0 & 3.1 \\
\hline Australian Cattle Dog & 30 & 28 & 2 & 0 & 3.3 \\
\hline Border Collie & 30 & 28 & 2 & 0 & 3.3 \\
\hline Collie & 30 & 28 & 2 & 0 & 3.3 \\
\hline Dobermann Pinscher & 30 & 28 & 2 & 0 & 3.3 \\
\hline Greyhound & 30 & 28 & 2 & 0 & 3.3 \\
\hline Waeller & 30 & 28 & 2 & 0 & 3.3 \\
\hline Whippet & 30 & 28 & 1 & 1 & 5.0 \\
\hline German shepherd dog & 31 & 28 & 3 & 0 & 4.8 \\
\hline Belgian Malenois & 30 & 27 & 1 & 2 & 8.3 \\
\hline Pug Dog & 30 & 27 & 3 & 0 & 5.0 \\
\hline Berger Blanc Suisse & 30 & 27 & 3 & 0 & 5.0 \\
\hline $\begin{array}{l}\text { Nova Scotia Duck Tolling } \\
\text { Retriever }\end{array}$ & 30 & 26 & 3 & 1 & 8.3 \\
\hline Magyar Vizsla & 29 & 24 & 5 & 0 & 8.6 \\
\hline Beagle & 34 & 28 & 6 & 0 & 8.8 \\
\hline Jack Russel Terrier & 30 & 24 & 6 & 0 & 10.0 \\
\hline Shetland Sheepdog & 30 & 24 & 5 & 1 & 11.7 \\
\hline Chihuahua & 27 & 21 & 5 & 1 & 13.0 \\
\hline Elo & 30 & 22 & 7 & 1 & 15.0 \\
\hline Kelpie & 30 & 20 & 10 & 0 & 16.7 \\
\hline Borsoi & 30 & 20 & 10 & 0 & 16.7 \\
\hline Groenendael & 31 & 19 & 11 & 1 & 21.0 \\
\hline Kangal & 35 & 17 & 12 & 6 & 34.3 \\
\hline Schapendoes & 30 & 9 & 16 & 5 & 43.3 \\
\hline Siberian Husky & 29 & 5 & 15 & 9 & 56.9 \\
\hline Chinese Shar-Pei & 32 & 2 & 17 & 13 & 67.2 \\
\hline
\end{tabular}

CYP2C41 genotypes: (-/), genotype with two mutant alleles, homozygous for the deletion; (+/-), genotype with one CYP2C41 and one mutant allele, heterozygous for the deletion; (+/+), genotype with two CYP2C41 alleles, homozygous; N, number of dogs studied for each breed.

led to an underestimation of the relative protein abundance of CYP2C41 in the canine liver.

\section{Catalytic Activity of CYP2C41}

Whereas in humans CYP2C8, CYP2C9, and CYP2C19 significantly contribute to liver drug metabolism (these enzymes account for $\sim 5,13$, and $7 \%$ of the metabolism of clinically used drugs, respectively) (27), the level of liver metabolism is not yet clear for the canine CYP2C21 and CYP2C41 enzymes.
In canines, both proteins constitute $\sim 24 \%$ of the total hepatic CYP proteins (30). In general, little is known about the catalytic activity and substrate specificity of CYP2C21 and CYP2C41, and so the clinical importance of the CYP2C41 gene deletion polymorphism remains largely unclear. Nevertheless, diclofenac and S-mephenytoin (marker substrates for human CYP2C9 and CYP2C19, respectively), as well as tramadol have already been identified as CYP2C21/CYP2C41 substrates in vitro (31-33), indicating potential pharmacogenetic relevance of these genes. However, a limitation of the present study is that the catalytic activity of CYP2C41 was not analyzed.

\section{CYP2C41 Gene Deletion Polymorphism}

There are two possible explanations of how the CYP2C41 gene polymorphism developed. The first possibility is that canine CYP2C21 and CYPC41 originated from a gene duplication event in the same gene cluster, and CYP2C41 was later deleted in certain breed lines by recombination. In this scenario, the CYP2C41 gene variation can be classified as a gene deletion polymorphism. The second possibility could just be a polymorphic gene duplication event in the CYP2C gene cluster that only occurred in individual subjects from certain breed lines. Although the second possibility cannot be completely ruled out, a gene deletion event seems much more likely for several reasons. First, CYP2C41 has much higher sequence identity with human $\mathrm{CYP} 2 \mathrm{C}$ genes and proteins than CYP2C21. Second, the CYP2C41 gene is somewhat smaller than the CYP2C21 gene, making gene duplication from CYP2C21 unlikely. Third, the recently available gray wolf genome reveals two genes, CYP2C21 and CYP2C41, within the CYP2C cluster and both are highly homologous to the canine orthologs. This overall provides support for speculation that CYP2C41 was the original gene in this gene cluster, and that after the duplication and divergence of the CYP2C21 gene, CYP2C41 was deleted by recombination. Finally, as highly homologous sequences upstream and downstream of the CYP2C41 gene were found, a deletion at these sites by homologous recombination seems likely, but an insertion seems unlikely. Based on these points, it can also be speculated that this deletion event occurred independently several times in individual subjects from different dog breed lines. However, as clustering of this CYP2C41 gene variation was found in certain breeds, the CYP2C41 gene deletion event might also have occurred only once in a single individual subject. Across all types of genetic variations, polymorphic deletions of entire genes are quite unusual. However, in humans a partial CYP2D6 gene deletion (34), and a complete deletion of the CYP2A6 gene (35) have been described.

\section{CONCLUSION}

In the present study an exact characterization of the canine CYP2C41 gene deletion polymorphism at the genomic level is provided. In addition, a genotyping method that was already tested in 1,089 individual subjects from 36 different breeds is presented. Interestingly, the site of gene deletion was identical for all CYP2C41 negative subjects, and all CYP2C41 subjects showed highly homologous sequence domains upstream and 

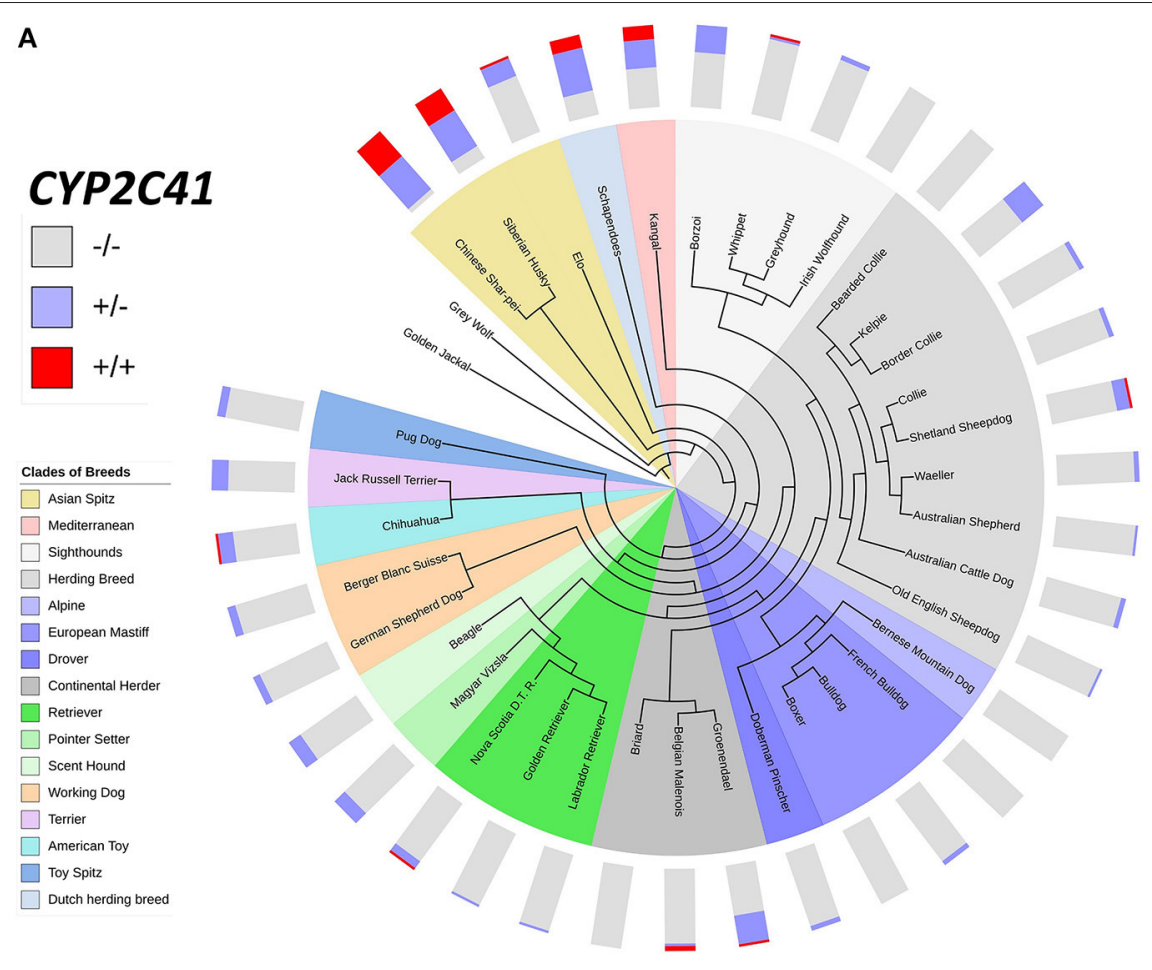

B

MDR1 nt230 (del4)

$\square+/+$
$\square+/-$
$\square-/-$

Clades of Breeds

$\square$ Asian Spitz

$\square$ Mediterranean

$\square$ sighthounds

$\square$ Herding Breed

$\square$ Alpine

$\square$ European Mastiff

$\square$ Drover

$\square$ Continental Herder

$\square$ Retriever

$\square$ Pointer Setter

$\square$ Scent Hound

$\square$ Working Dog

$\square$ Terrier

$\square$ American Toy

$\square$ Dutch herding breed

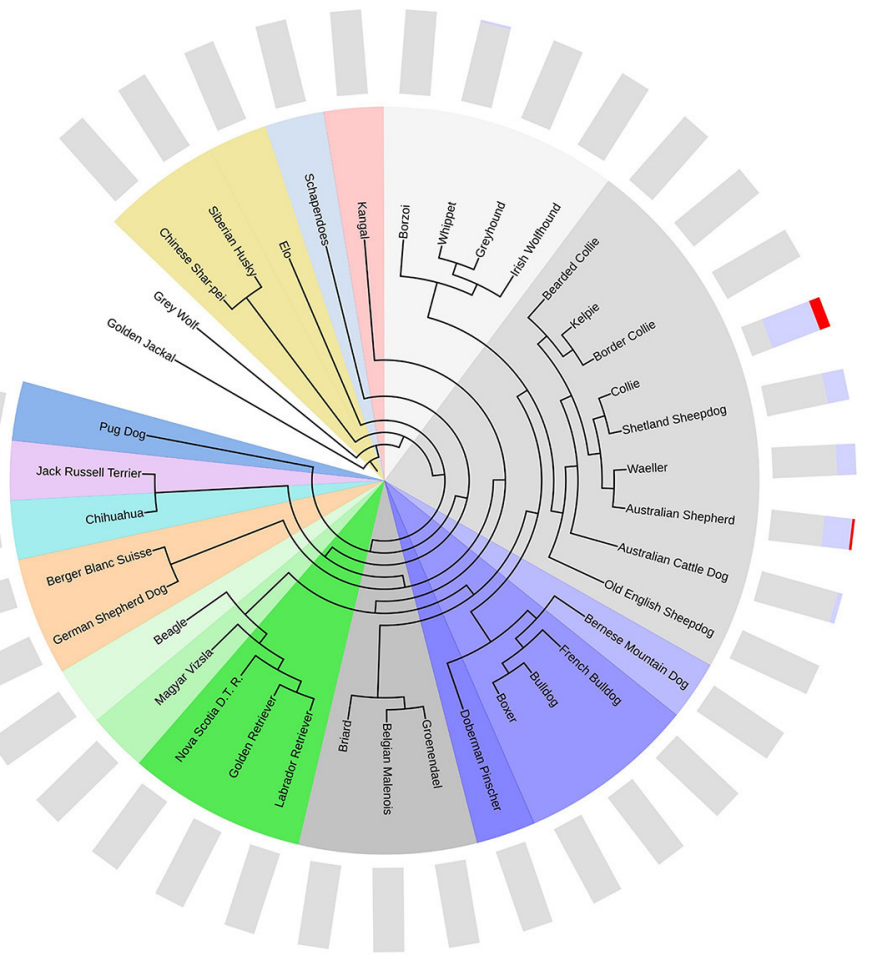

FIGURE 4 | Continued 


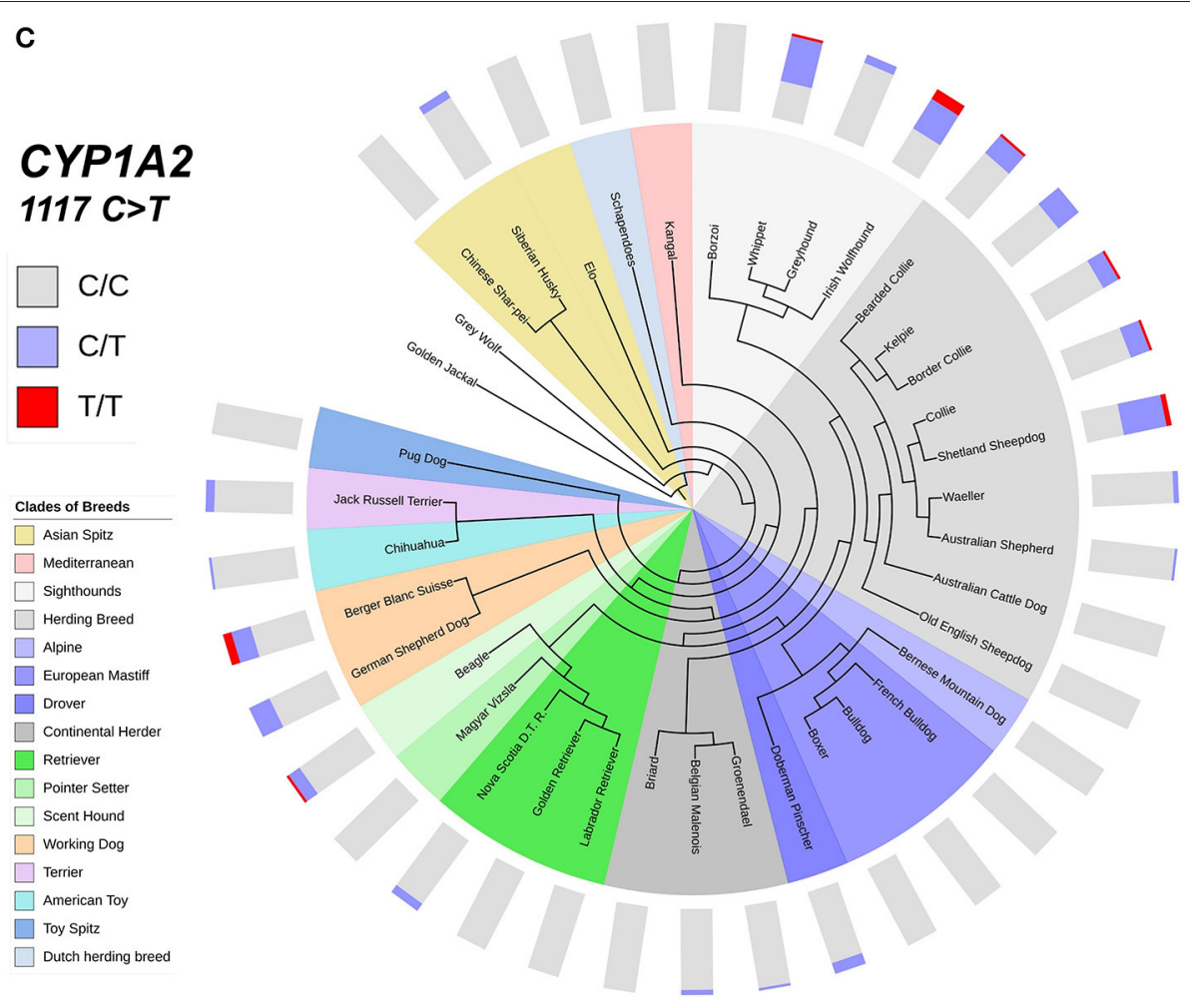

FIGURE 4 | Comparative genotyping for CYP2C41, MDR1, and CYP1A2. All subjects listed in Table 5 were genotyped for CYP2C41 (A), and also for the occurrence of the nt230(del4) MDR1 mutation (B), and the CYP1A2 1117C>T single nucleotide polymorphism (C). Charting of phylogenetic relationships and rooting of the 36 analyzed breeds was carried out according to Parker et al. (20). The phylogenetic tree was adapted to and displayed with the Interactive Tree Of Life (iTOL) tool (http:// itol.embl.de/). The clustering of breeds (see color code) was carried out according to Parker et al. (20). The breeds Schapendoes, Elo, and Groenendael were included and grouped according to their breed history. Bar charts show color-coded percentage genotype distributions.

downstream from the CYP2C41 gene, at which homologous recombination likely occurred. The CYP2C41 genotyping test can now be used in future canine pharmacokinetic studies to identify genetically based poor or extensive drug metabolizers. These results, together with more extensive in vitro drug screening for CYP2C41 substrates, will help to determine the clinical relevance of CYP2C41, and to optimize drug treatment. Although the CYP2C41 relative protein abundance in the canine liver seems not to be very high, this CYP could substantially contribute to hepatic drug metabolism in subjects that express CYP2C41 at both alleles, and when CYP2C41 shows higher catalytic activity in response to a given drug than other hepatic metabolic enzymes.

\section{DATA AVAILABILITY STATEMENT}

The datasets presented in this study can be found in online repositories. The names of the repository/repositories and accession number(s) can be found in the article/supplementary material.

\section{ETHICS STATEMENT}

Ethical review and approval was not required for the animal study because blood samples from client-owned dogs were originally nt230(del4) MDR1 genotyped for clinical diagnostic reasons as part of the pharmacogenetic diagnostic service at the host institute. Some of these DNA samples then were used for retrospective CYP2C41 genotyping. The dog owners gave consent that the DNA samples can be used for subsequent scientific studies instead of being discarded. No samples were taken specifically for the retrospective analysis presented in the current manuscript and, therefore, this re-analysis did not require ethical approval.

\section{AUTHOR CONTRIBUTIONS}

EK, SL, and JG conceived the experiments, analyzed and interpreted the results. $\mathrm{EK}, \mathrm{SL}$, and $\mathrm{CP}$ performed the experiments. EK and JG wrote the manuscript. All authors approved the manuscript.

\section{FUNDING}

This study was supported by grants to EK from the Scholar Rescue Fund and by the Philipp Schwartz-Initiative of the Alexander von Humboldt-Stiftung. 


\section{ACKNOWLEDGMENTS}

The authors thank Regina Leidolf for technical assistance and Laurence Henry for critical reading of the manuscript.

\section{REFERENCES}

1. Fink-Gremmels J. Implications of hepatic cytochrome P450-related biotransformation processes in veterinary sciences. Eur J Pharmacol. (2008) 585:502-9. doi: 10.1016/j.ejphar.2008.03.013

2. Court MH. Canine cytochrome P-450 pharmacogenetics. Vet Clin North Am Small Anim Pract. (2013) 43:1027-38. doi: 10.1016/j.cvsm.2013. 05.001

3. Fleischer S, Sharkey $M$, Mealey $K$, Ostrander EA, Martinez $M$. Pharmacogenetic and metabolic differences between dog breeds: Their impact on canine medicine and the use of the dog as a preclinical animal model. AAPS J. (2008) 10:110-9. doi: 10.1208/s12248-008-9011-1

4. Mealey KL, Martinez SE, Villarino NF, Court MH. Personalized medicine: going to the dogs? Hum Genet. (2019) 138:467-81. doi: 10.1007/s00439-019-02020-w

5. Martinez MN, Antonovic L, Court M, Dacasto M, Fink-Gremmels J, Kukanich $\mathrm{B}$, et al. Challenges in exploring the cytochrome P450 system as a source of variation in canine drug pharmacokinetics. Drug Metab Rev. (2013) 45:21830. doi: 10.3109/03602532.2013.765445

6. Mise M, Hashizume T, Matsumoto S, Terauchi Y, Fujii T. Identification of non-functional allelic variant of CYP1A2 in dogs. Pharmacogenetics. (2004) 14:769-73. doi: 10.1097/00008571-200411000-00008

7. Tenmizu D, Endo Y, Noguchi K, Kamimura H. Identification of the novel canine CYP1A2 1117 C > T SNP causing protein deletion. Xenobiotica. (2004) 34:835-46. doi: 10.1080/00498250412331285436

8. Mise M, Yadera S, Matsuda M, Hashizume T, Matsumoto S, Terauchi Y, et al. Polymorphic expression of CYP1A2 leading to interindividual variability in metabolism of a novel benzodiazepine receptor partial inverse agonist in dogs. Drug Metab Dispos. (2004) 32:240-5. doi: 10.1124/dmd.32.2.240

9. Mise M, Hashizume T, Komuro S. Characterization of substrate specificity of dog CYP1A2 using CYP1A2-deficient and wild-type dog liver microsomes. Drug Drug Metab Dispos. (2008) 36:1903-8. doi: 10.1124/dmd.108. 022301

10. Tenmizu D, Noguchi K, Kamimura H, Ohtani H, Sawada Y. The canine CYP1A2 deficiency polymorphism dramatically affects the pharmacokinetics of 4-cyclohexyl-1-ethyl-7-methylpyrido[2,3-d]pyrimidine-2-(1H)-one (YM64227), a phosphodiesterase type 4 inhibitor. Drug Metab Dispos. (2006) 34:800-6. doi: $10.1124 / \mathrm{dmd} .105 .008722$

11. Kraus BLH, Greenblatt DJ, Venkatakrishnan K, Court MH. Evidence for propofol hydroxylation by cytochrome P4502B11 in canine liver microsomes: breed and gender differences. Xenobiotica. (2000) 30:575-88. doi: 10.1080/004982500406417

12. Martinez SE, Andresen MC, Zhu Z, Papageorgiou I, Court MH. Pharmacogenomics of poor drug metabolism in Greyhounds: Cytochrome P450 (CYP) 2B11 genetic variation, breed distribution, and functional characterization. Sci Rep. (2020) 10:69. doi: 10.1038/s41598-019-56660-z

13. Blaisdell J, Goldstein JA, Bai SA. Isolation of a new canine cytochrome P450 cDNA from the cytochrome P450 2C subfamily (CYP2C41) and evidence for polymorphic differences in its expression. Drug Metab Dispos. (1998) 26:27883.

14. Gramer I, Leidolf R, Döring B, Klintzsch S, Kramer EM, Yalcin E, et al. Breed distribution of the nt230(del4) MDR1 mutation in dogs. Vet J. (2011) 189:67-71. doi: 10.1016/j.tvjl.2010.06.012

15. Klintzsch S, Meerkamp K, Döring B, Geyer J. Detection of the nt230[del4] MDR1 mutation in dogs by a fluorogenic 5' nuclease TaqMan allelic discrimination method. Vet J. (2010) 185:272-7. doi: 10.1016/j.tvjl.2009.07.018

\section{SUPPLEMENTARY MATERIAL}

The Supplementary Material for this article can be found online at: https://www.frontiersin.org/articles/10.3389/fvets. 2021.663175/full\#supplementary-material

16. Aretz JS, Geyer J. Detection of the CYP1A2 1117C > T polymorphism in 14 dog breeds. J Vet Pharmacol Ther. (2011) 34:98-100. doi: 10.1111/j.1365-2885.2010.01222.x

17. Mealey KL, Bentjen SA, Gay JM, Cantor GH. Ivermectin sensitivity in collies is associated with a deletion mutation of the mdrl gene. Pharmacogenetics. (2001) 11:727-33. doi: 10.1097/00008571-200111000-00012

18. Geyer J, Döring B, Godoy JR, Leidolf R, Moritz A, Petzinger E. Frequency of the nt230 (del4) MDR1 mutation in Collies and related dog breeds in Germany. J Vet Pharmacol Ther. (2005) 28:545-51. doi: 10.1111/j.1365-2885.2005.00692.x

19. Neff MW, Robertson KR, Wong AK, Safra N, Broman KW, Slatkin M, et al. Breed distribution and history of canine mdr1-1Delta, a pharmacogenetic mutation that marks the emergence of breeds from the collie lineage. Proc Natl Acad Sci USA. (2004) 101:11725-30. doi: 10.1073/pnas.04023 74101

20. Parker HG, Dreger DL, Rimbault M, Davis BW, Mullen AB, CarpinteroRamirez G, et al. Genomic analyses reveal the influence of geographic origin, migration, and hybridization on modern dog breed development. Cell Rep. (2017) 19:697-708. doi: 10.1016/j.celrep.2017.03.079

21. Goldstein JA, de Morais SM. Biochemistry and molecular biology of the human CYP2C subfamily. Pharmacogenetics. (1994) 4:285-99. doi: 10.1097/00008571-199412000-00001

22. Soucek P, Gut I. Cytochromes P-450 in rats: structures, functions, properties and relevant human forms. Xenobiotica. (1992) 22:83-103. doi: 10.3109/00498259209053106

23. Renaud HJ, Cui JY, Khan M, Klaassen CD. Tissue distribution and genderdivergent expression of 78 cytochrome P450 mRNAs in mice. Toxicol Sci. (2011) 124:261-77. doi: 10.1093/toxsci/kfr240

24. Ono Y, Sugiyama S, Matsushita M, Kitazawa T, Amano T, Uno Y, et al. Limited expression of functional cytochrome p450 2c subtypes in the liver and small intestine of domestic cats. Xenobiotica. (2019) 49:627-35. doi: 10.1080/00498254.2018.1483543

25. Leiberich M, Marais HJ, Naidoo V. Phylogenetic analysis of the cytochrome P450 (CYP450) nucleotide sequences of the horse and predicted CYP450s of the white rhinoceros (Ceratotherium simum) and other mammalian species. PeerJ. (2018) 6:e5718. doi: 10.7717/peerj.5718

26. Gaedigk A, Ingelman-Sundberg M, Miller NA, Leeder JS, Whirl-Carrillo $\mathrm{M}$, Klein TE, et al. The pharmacogene variation (PharmVar) consortium: incorporation of the human cytochrome P450 (CYP) allele nomenclature database. Clin Pharmacol Ther. (2018) 103:399-401. doi: 10.1002/cpt.910

27. Zanger UM, Schwab M. Cytochrome $\mathrm{P} 450$ enzymes in drug metabolism: regulation of gene expression, enzyme activities, and impact of genetic variation. Pharmacol Ther. (2013) 138:103-41. doi: 10.1016/j.pharmthera.2012.12.007

28. Graham MJ, Bell AR, Crewe HK, Moorcraft CL, Walker L, Whittaker EF, et al. mRNA and protein expression of dog liver cytochromes P450 in relation to the metabolism of human CYP2C substrates. Xenobiotica. (2003) 33:225-37. doi: 10.1080/0049825021000048782

29. Martinez SE, Shi J, Zhu HJ, Jimenez TEP, Zhu ZH, Court MH. Absolute quantitation of drug-metabolizing cytochrome P450 enzymes and accessory proteins in dog liver microsomes using label-free standard-free analysis reveals interbreed variability. Drug Metab Dispos. (2019) 47:1314-24. doi: 10.1124/dmd.119.088070

30. Achour B, Barber J, Rostami-Hodjegan A. Expression of hepatic drug-metabolizing cytochrome P450 enzymes and their intercorrelations: a meta-analysis. Drug Metab Dispos. (2014) 42:1349-56. doi: $10.1124 / \mathrm{dmd} .114 .058834$ 
31. Shou MG, Norcross R, Sandig G, Lu P, Li YH, Lin Y, et al. Substrate specificity and kinetic properties of seven heterologously expressed dog cytochromes P450. Drug Metab Dispos. (2003) 31:1161-9. doi: 10.1124/dmd.31. 9.1161

32. Locuson CW, Ethell BT, Voice M, Lee D, Feenstra KL. Evaluation of Escherichia coli membrane preparations of canine CYP1A1, 2B11, 2C21, 2C41, 2D15, 3A12, and 3A26 with coexpressed canine cytochrome P450 reductase. Drug Metab Dispos. (2009) 37:457-61. doi: $10.1124 /$ dmd.108.025312

33. Jimenez TEP, Mealey KL, Schnider D, Grubb TL, Greene SA, Court $\mathrm{MH}$. Identification of canine cytochrome P-450s (CYPs) metabolizing the tramadol $(+)-\mathrm{M} 1$ and $(+)-\mathrm{M} 2$ metabolites to the tramadol (+)-M5 metabolite in dog liver microsomes. J Vet Pharmacol Ther. (2018) 41:815-24. doi: $10.1111 /$ jvp.12706

34. Ingelman-Sundberg M. Genetic polymorphisms of cytochrome P450 2D6 (CYP2D6): clinical consequences, evolutionary aspects and functional diversity. Pharmacogenomics J. (2005) 5:6-13. doi: 10.1038/sj.tpj.6500285
35. Nakajima M, Yamagishi S, Yamamoto H, Yamamoto T, Kuroiwa Y, Yokoi T Deficient cotinine formation from nicotine is attributed to the whole deletion of the CYP2A6 gene in humans. Clin Pharmacol Ther. (2000) 67:57-69. doi: $10.1067 / \mathrm{mcp} .2000 .103957$

Conflict of Interest: The authors declare that the research was conducted in the absence of any commercial or financial relationships that could be construed as a potential conflict of interest. The authors declare that nt230(del4) MDR1 genotyping is a commercial diagnostic service of their host institute.

Copyright (c) 2021 Karakus, Prinzinger, Leiting and Geyer. This is an open-access article distributed under the terms of the Creative Commons Attribution License (CC BY). The use, distribution or reproduction in other forums is permitted, provided the original author(s) and the copyright owner(s) are credited and that the original publication in this journal is cited, in accordance with accepted academic practice. No use, distribution or reproduction is permitted which does not comply with these terms. 